\title{
STIMULATION OF UTERINE RNA SYNTHESIS IN MICE BY THE POST-COITAL ANTIFERTILITY AGENT, ORF 3858
}

\author{
F. G. GREENSLADE AND D. W. HAHN \\ Ortho Research Foundation, Raritan, New Jersey 08869, U.S.A.
}

(Received 18th March 1975)

Oestrogens, according to Emmens \& Miller (1969), may be pharmacologically categorized into three classes: (1) compounds which occupy receptor sites and thereby elicit immediate physiological responses, (2) compounds which weakly or briefly occupy receptors and therefore result in impeded responses, and (3) pro-oestrogens, compounds which must undergo metabolic transformation in order to elicit oestrogenic responses.

The compound 2-methyl-3-ethyl-4-phenyl-4-cylohexene carboxylic acid (ORF 3858) is non-steroidal and has post-coital antifertility and oestrogenic properties (Blye \& Homm, 1967; Blye, 1970). During studies of the mechanism of the antifertility activity of this compound, two interesting experimental observations were made. First, when metabolic transformation of ORF 3858 to a $p$-hydroxylated form was inhibited, the antifertility activity of the compound was lost (Yard et al., 1969). Second, ORF 3858 was found not to bind to uterine cytosol oestrogen receptors, whereas the $p$-hydroxylated analogue bound with high affinity (McGuire et al., 1971). These findings suggested that the antifertility activity of the compound is related to the oestrogenicity of a metabolite and that ORF 3858 is a pro-oestrogen according to the scheme of Emmens \& Miller (1969). The present study examines this hypothesis.

One of the most immediate cellular responses to oestrogens is the acceleration of uterine (or vaginal) RNA synthesis (O'Malley \& Means, 1974). This sensitive end-point allows the measurement of the onset (Hahn et al., 1971) and the duration (Miller \& Emmens, 1967) of target level responses after a single administration of oestrogenic drugs. In this study, $0.1 \mu \mathrm{g}$ of ORF 3858 or its $p$-hydroxylated congener, ORF 5531, was injected subcutaneously in $0.1 \mathrm{ml}$ of $5 \% \mathrm{EtOH}$ in $0.9 \% \mathrm{NaCl}$ into female mice which weighed 25 to $30 \mathrm{~g}$ and had been ovariectomized 14 to 18 days previously. At various times after injection and $2 \mathrm{hr}$ before autopsy, the mice received $6 \mu \mathrm{Ci}\left[{ }^{3} \mathrm{H}\right]$ uridine in $0.2 \mathrm{ml}$ of $0.9 \% \mathrm{NaCl}$ via the lateral tail vein. The uteri were removed, pooled according to the treatment group, and immediately frozen in dry ice. Total RNA synthesis was measured by a modification of the method of Miller \& Emmens (1967). Samples were homogenized in distilled water, and homogenates were made $0 \cdot 2$ $\mathrm{N}$ with respect to perchloric acid (PCA). The PCA precipitates were allowed to form overnight and were washed in $0.2 \mathrm{~N}$-PCA. Washed precipitates were collected by filtration on Whatman No. 2 filter paper. The precipitates were 
then air dried, combusted in a Packard sample oxidizer, and measured for radioactivity using an Intertechnique Model SL-30 spectrometer. The experiment was done in duplicate, each sample consisting of both uteri from a single mouse.

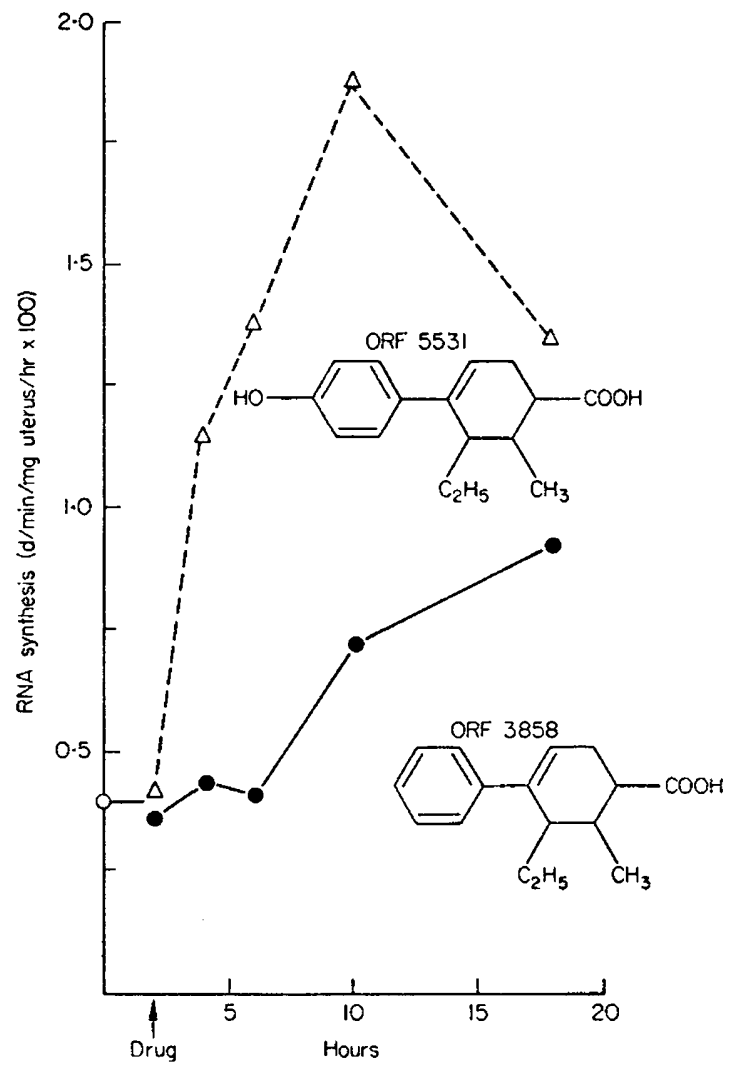

TEXT-FIG. 1. Incorporation of tritiated uridine into uterine RNA after injection of $0 \cdot 1$ $\mu \mathrm{g}$ ORF $3858(0)$ or ORF $5531(\Delta)$. The open circle $(0)$ is the incorporation rate in animals before the administration of the drug. Each point is the mean of duplicate samples.

The baseline rate of $\left[{ }^{3} \mathrm{H}\right]$ uridine incorporation into uterine RNA in this experiment was $40 \mathrm{~d} / \mathrm{min} / \mathrm{mg}$ wet $\mathrm{wt} / \mathrm{hr}$. The injection of ORF 5531 resulted in an immediate increase in the rate of RNA synthesis to a $4 \cdot 7$-fold peak within 8 hr (Text-fig. 1). Virtually identical time courses for RNA synthesis have been found for oestradiol-17 $\beta$ (F. G. Greenslade, unpublished data), ethinyl oestradiol (Hahn et al., 1971) and a variety of other steroidal and non-steroidal oestrogens (Miller \& Emmens, 1967). Injection of ORF 3858 did not lead to an immediate increase in uterine RNA synthesis; the rate remained virtually without change at background levels for several hours before it increased to a maximum rate ( $\times 2.5$ the background rate by $16 \mathrm{hr}$ after injection). When measured at $32 \mathrm{hr}$ after injection, the synthesis rates induced by both com- 
pounds had returned to levels slightly below those found before administration of the drug.

An interpretation of this delay in the uterine RNA synthetic response to ORF 3858 is that a period of time is required for metabolic conversion to the $p$-hydroxylated form, which is recognizable by the uterine oestrogen receptor. These and previous data from our laboratory lead us to conclude, therefore, that the post-coital antifertility action of ORF 3858 lies in its activity as a prooestrogen.

\section{REFERENCES}

BLYE, R.P. (1970) The effect of estrogens and related substances on embryonic viability. Adv. Biosci. 4, $326-343$.

Blye, R.P. \& Номм, R. (1967) Antizygotic activity of 2-methyl-3-ethyl-4-phenyl-4-cyclohexene carboxylic acid in the rat. Fedn Proc. Fedn Am. Socs exp. Biol. 26, 486.

Emmens, C.W. \& Miller, B.G. (1969) Estrogens, proestrogens and antiestrogens. Steroids 13, 725-730.

Hahn, D.W., McGurRe, J.L., Greenslade, F.C. \& Turner, G.D. (1971) Molecular parameters involved in the estrogenicity of mestranol and ethinylestradiol. Proc. Soc. exp. Biol. Med. 137, $1180-1185$

MaGuire, J.L., Turner, G.D. \& GreensLade, F.C. (1971) Studies on the effect of 2-methyl-3-ethyl-4phenyl- $\Delta^{4}$-cyclohexene carboxylic acid (ORF 3858) and its $p$-hydroxylated metabolites on uptake of ${ }^{3} \mathrm{H}$-estradiol-17 $\beta$ by the uterus. Proc. Soc. exp. Biol. Med. 136, 146-149.

Miller, B.G. \& Emmens, C.W. (1967) The incorporation of tritiated uridine in the genital tract of the oestrogen treated mouse. 7. Endocr. 39, 473-484.

O'Malley, B.W. \& Means, A.R. (1974) Female steroid hormones and target cell nuclei. Science, N.Y. $183,610-620$.

Yard, A.S., Juhasz, L. \& Grimes, R.M. (1969) Studies on the anti-fertility effects and metabolism of a new, postcoital oral contraceptive, 2-methyl-3-ethyl-4-phenyl- $\Delta^{4}$-cyclohexene carboxylic acid, sodium salt (ORF 3858). F. Pharmac. exp. Ther. 167, 105-116. 